Jurnal Keperawatan Silampari

Volume 3, Nomor 1, Desember 2019

e-ISSN: 2581-1975

p-ISSN: 2597-7482

DOI: https://doi.org/10.31539/jks.v3i1.820

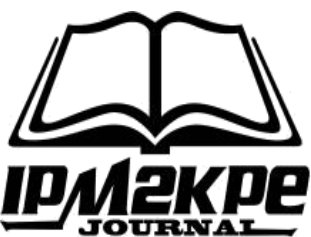

\title{
PENGARUH PEMBERIAN PERMEN KARET XYLITOL TERHADAP KESEHATAN MULUT (XEROSTOMIA) PADA PASIEN CHRONIC KIDNEY DISEASE (CKD)
}

\author{
Peri Zuliani ${ }^{1}$, Busjra M. Nur ${ }^{2}$, Rohman Azzam ${ }^{3}$ \\ Program Studi Keperawatan, STIKES Bhakti Husada Bengkulu ${ }^{1}$ \\ Program Studi Magister Keperawatan, Universitas Muhammadiyah Jakarta ${ }^{2,3}$ \\ perizuliani1@gmail.com ${ }^{1}$
}

\begin{abstract}
ABSTRAK
Tujuan dari penelitian ini adalah untuk mengetahui apakah terdapat pengaruh pemberian permen karet xylitol pada pasien CKD. Jenis penelitian ini adalah eksperimen kuantitatif dengan desain pre post test design dengan jumlah sampel yang diambil sebanyak 20 responden. Kesehatan Mulut responden diukur dengan menggunakan kuesioner OHIP dengan skala likert dan skoring. Hasil penelitian didapatkan ada perbedaan kesehatan mulut sebelum dan setelah diberikan permen karet xylitol dengan nilai $\rho$ value $<0.05$. Simpulan, pemberian permen karet Xylitol berpengaruh terhadap kesehatan mulut (xerostomia) pasien CKD.
\end{abstract}

Kata Kunci: CKD, Kesehatan Mulut (Xerostomia), Xylitol

\begin{abstract}
The purpose of this study was to determine whether there is an influence of xylitol gum administration in CKD patients. This type of research is a quantitative experiment with a pre post test design with a total sample of 20 respondents. Oral health of respondents was measured using the OHIP questionnaire with a Likert scale and scoring. The results showed there were differences in oral health before and after being given xylitol gum with a value of $\rho$ value $<0.05$. Conclusion, administration of Xylitol gum affects the oral health (xerostomia) of CKD patients.
\end{abstract}

Keywords: CKD, Oral Health (Xerostomia), Xylitol

\section{PENDAHULUAN}

World Health Oranization (WHO) memperkirakan bahwa lebih dari 346 juta orang di seluruh dunia mengidap diabetes. Jumlah ini kemungkinan akan lebih dari dua kali lipat pada tahun 2030 tanpa intervensi. Hampir 80\% kematian diabetes terjadi di Negara berpenghasilan rendah dan menengah. Menurut laporan WHO, India saat ini mempunyai jumlah terbesar didunia dengan lebih dari 32 juta klien dengan diabetes mellitus dan jumlah ini diprediksikan meningkat menjasi 79,4 juta pada tahun 2030 (WHO, 2016). Diabetes mellitus kini tumbuh menjadi masalah kesehatan dunia, International Diabetes Federation (IDF) menunjukkan prevalensi DM didunia dari 371 juta kasus pada 2012 meningkat 55\% menjadi 592 juta pada 2035 (IDF, 2015). 
Kenaikan insiden DM juga terjadi di Asia tenggara. Total populasi di Asia tenggara pada rentang usia 20-79 tahun sebanyak 838 juta jiwa pada tahun 2010. Dari total populasi tersebut terdapat 58,7 juta jiwa $(7,6 \%)$ pasien DM tipe 2 . Jumlah tersebut meningkat pada tahun 2030, yaitu total populasi pada rentang usia 20-79 tahun sebanyak 1,2 miliar, terdapat 101 juta $(9,1) \%$ DM tipe 2. Angka kejadian DM tipe 2 pada usia dewasa antara 20-70 th diseluruh dunia pada tahun 2015 meningkat menjadi 415 juta dan akan diperkirakan mencapai 642 juta orang pada tahun 2040. Berdasarkan IDF, diketahui terjadi kenaikan prevalensi DM di dunia tahun 2-13 sebesar 8,3\% menjadi 8,8\% pada tahun 2015 (IDF, 2015).

American Diabetes Association (ADA) pada tahun 2018 mengemukakan bahwa diabetes mellitus merupakan sindrom metabolik dengan karakteristik hiperglikemi yang terjadi karena kelainan sekresi insulin, kerja insulin atau kedua-duanya yang ditandai dengan pulyuria, polydipsia, polyphagia disertai kehilangan berat badab yang tidak jelas penyebabnya. Diabetes mellitus diklasifikasikan menjadi 4 tipe, yaitu diabetes mellitus tipe 1, diabetes mellitus tipe 2, diabetes mellitus tipe lain, dan diabetes mellitus gestasional pada kehamilan (ADA, 2018).

Indonesia merupakan salah satu negara berkembang yang memiliki angka kejadian DM tipe 2 yang cukup tinggi. Jumlah penderita DM tipe 2 di Indonesia pada tahun 2010 mencapai 8,4 juta jiwa dan diperkirakan pada tahun 2030 akan mengalami peningkatan menjadi 21,3 juta jiwa (ADA, 2017).

Pada pasien yang menderita DM tipe 2 akan mengalami penurunan fungsi organ baik karena faktor alamiah maupun penyakit. Salah satu hal yang terkait dengan itu yaitu keluhan mulut kering (xerostomia). Keadaan ini disebabkan karena terjadi atropi pada kelenjar saliva yang akan menurunkan produksi saliva dan mengubah komposisinya (Amelia, 2012). Xerostomia dapat terjadi pada berbagai penyakit antara lain, gagal ginjal kronis, Kelainan saraf yang diikuti gejala degenerasi, seperti Sklerosis multiple, penderita AIDS, Rematoid arthritis, termasuk Diabetes mellitus.

Prevalensi xerostomia pada populasi umum masih belum jelas karena terbatasnya jumlah studi. Prevalensi yang dilaporkan bervariasi, mulai dari 0,9\% hingga 64,8\% . Insiden xerostomia meningkat dari $6 \%$ pada usia 50 tahun dan $15 \%$ pada usia 65 tahun (Kusuma, 2012). Salah satu temuan memperkirakan terjadinya xerostomia pada usia 65 tahun menjadi sekitar $30 \%$ pasien yang hidup dengan pengobatan jangka panjang, seperti pada psien yang menggunakan obat psikiatri, anti hipertensi atau kelianan ginjal (Rizqi, 2013).

Mulut kering (Xerostomia) diindikasikan sebagai penurunan produksi saliva. Beberapa faktor penyebab antara lain yaitu efek samping obat dan tingkat stress pada penderita DM tipe 2. Efek samping obat tersebut akan menurunkan produksi saliva sehingga kadar asam di dalam mulut meningkat. Dengan jumlah yang sedikit dan konsistensi yang kental, saliva akan kehilangan fungsinya sebagai pembersih alami rongga mulut. Keadaan emosial seperti stress, putus asa dan rasa takut yang dialami penderita DM tipe 2 dapat merangsang system saraf simpatis dan menghalangi sistem saraf parasimpatis sehingga sekresi saliva menurun dan menyebabkan mulut menjadi kering (Amelia, 2012). Xerostomia pada DM tipe 2 terjadi karena gangguan neuropati atau karena adanya kerusakan pada nervus kranial VII (nervus fasialis) dan nervus kranialis IX (nervus glosofaringeal) yaitu nervus yang menginervasi kelenjar parotis sumber penghasil saliva. 
Xerostomia akan terjadi ketika aliran saliva menurun hingga 50\% dari sekresi normal. Penurunan curah saliva menyebabkan berubahnya komposisi pada saliva seperti bikarnonat, fosfat dan urea yang berkurang sehingga menyebabkan penurunan kapasitas bufferI saliva yang menghasilkan menurunnya $\mathrm{pH}$ (Pinna, Campus, Cumbo, Mura \& Milia, 2015). Apabila terjadi peningkatan ataupun penurunan volume saliva, maka akan diikuti dengan peningkatan atau penurunan $\mathrm{pH}$ saliva sebesar 78,5\%. Meningkatnya sekresi saliva menyebabkan meningkatnya volume dan mengencerkan saliva yang diperlukan untuk proses penelanan dan lubrikasi. Peningkatan sekresi saliva juga meningkatkan jumlah dan kandungan saliva, seperti bikarbonat yang dapat meningkatkan $\mathrm{pH}$. Sebaliknya menurunnya sekresi saliva akan menurunkan jumlah dan susunan kandungan saliva yang dapat menyebabkan menurunnya $\mathrm{pH}$ saliva (Marasabessy, 2013).

Peranan saliva dalam rongga mulut sangat penting, maka perlu diupayakan penanggulangan terhadap penurunan curah saliva pada penderita diabetes mellitus yang dapat dilakukan dengan merangsang mastikasi, terutama dengan menggunakan permen karet xylitol. Salah satu bahan kimia yang telah diteliti dan terbukti efektif dalam menginduksi produksi saliva dan aman bagi penderita diabetes mellitus tipe 2 adalah xylitol. Xylitol telah dibuktikan dalam berbagai study klinis sebagai suatu stabilizer insulin alami yang sangat lambat dimetabolisme dan tidak menyebabkan perubahan glukosa secara drastis, sehingga permen karet yang mengandung xylitol baik digunakan sebagai pembersih rongga mulut (Rara Astria, 2014).

Saliva berperan penting bagi kesehatan rongga mulut. Fungsi saliva yang penting dan sangat jelas yaitu saat makan, untuk mengecap dan menjadi pelumas bagi makanan dan melindungi mukosa dan gigi, air, dan glikoprotein menjadi pelumas bagi makanan dan membantu proses menelan. Saliva juga penting untuk persepsi rasa yang normal. Salah satu faktor yang dapat mempengaruhi komposisi saliva adalah laju aliran saliva. Sekresi saliva yang menurun akan menyebabkan rasa ketidaknyamanan pada rongga mulut, nyeri, peningkatan tingkat karies gigi dan infeksi mulut, serta kesulitan berbicara dan menelan makanan, sehingga asupan gizi pun menurun diikuti dengan penurunan berat badan. Keluhan-keluhan yang muncul akibat xerostomia ini dapat mempengaruhi kesehatan mulut yang nantinya akan mempengaruhi tingkat kualitas hidup pula (Rizky, 2013).

Salah satu bahan kimia yang telah diteliti dan terbukti efektif dalam menginduksi produksi saliva adalah xylitol yang digunakan dalam bentuk produk permen karet. Pada penelitian sebelumnya, terbukti bahwa permen karet yang mengandung Xylitol dapat bermanfaat untuk merangsang produksi saliva, meningkatkan $\mathrm{pH}$ plak dan saliva, sehingga sangat baik digunakan sebagai pembersih rongga mulut (Rizky, 2013).

Mengonsumsi produk yang mengandung xylitol adalah salah satu alternatif untuk memelihara kesehatan gigi dan mulut. Xylitol adalah pemanis alami yang bermanfaat dalam menekan jumlah bakteri mulut, menghambat pertumbuhan plak, mencegah keasaman plak, dan mempercepat proses pembentukan kembali mineral gigi. Xylitol telah terbukti mampu menjaga kesehatan mulut dengan cara menekan jumlah bakteri yang dapat menyebabkan gigi berlubang. Sehubungan dengan pernyataan tersebut, kini xylitol telah banyak diaplikasikan dalam banyak produk kesehatan seperti permen karet, obat kumur, dan pasta gigi (Agrianthy, 2014).

Pada tahun 1983, JFCFA (suatu komite gabungan antara WHO dan FAO) memutuskan bahwa xylitol merupakan pemanis yang aman untuk dikonsumsi, sehingga xylitol banyak diproduksi dalam bentuk permen karet. Xylitol merupakan pemanis yang 
aman bagi penderita Diabetes Mellitus dan hiperglikemia, sehingga banyak digunakan dan xylitol diabsorsi lebih lambat daripada gula biasa karena memiliki indeks glikemik yang sangat rendah yaitu 7, sedangkan gula biasa memiliki indeks glikemik sampai 90 dan dilepaskan ke dalam darah 13 kali lebih cepat dibanding xylitol (Sari, 2011).

Pemberian permen karet yang mengandung xylitol mempunyai efek menstimulasi produksi saliva. Permen karet bebas gula adalah cara yang sangat praktis untuk merangsang saliva. Banyak penelitian didunia yang mendukung tentang efek mengunyah permen karet bebas gula. Pemberian permen karet yang mengandung xylitol sesudah makan makanan yang mengandung karbohidrat, mempunyai efek meningkatkan buffer saliva dan mempunyai efek menurunkan akumulasi plak, mengurangi pertumbuhan bakteri, meningatkan kesehatan gusi dan gigi, dan mencegah bau mulut (Dewi, 2008).

Kesehatan mulut menurut World Health Organization (WHO) memiliki arti bebas dari nyeri kronik pada rongga mulut dan wajah, kanker rongga mulut dan tenggorokan, luka pada rongga mulut, kelainan kengenital seperti bibir atau palatum sumbing, penyakit periodontal, kerusakan dan kehilangan gigi, dan penyakit atau gangguan lainnya yang mempengaruhi rongga mulut (Amelia, 2012).

Berdasarkan uraian diatas, xerostomia dapat menimbulkan berbagai keluhan yaitu mukosa mulut kering, nyeri serta kesulitan mengunyah dan menelan. Pada penelitian sebelumnya hanya melihat kesehatan mulut terhadap kualitas hidup orang yang menderita xerostomia.

\section{METODE PENELITIAN}

Rancangan penelitian yang digunakan adalah one group pretest postest, rancangan ini tidak ada kelompok pembanding (kontrol), tetapi dilakukan pretest sebelum diberi perlakuan yang memungkinkan menguji perubahan- perubahan yang terjadi setelah adanya eksperimen. Sampel pada penelitian ini berjumlah 20 orang.

Variabel Kesehatan Mulut diukur menggunakan kuesioner Oral Health Impac Profile (OHIP) menggunakan kuesioner oral health impac profile-14 (OHIP-14) yang dikembangkan menjadi 15 pertanyaan. Oral health impac profile dikembangkan bertujuan untuk memberikan ukuran komprehensif tentang disfungsi, ketidak nyamanan dan kecacatan yang disebabkan oleh kondisi mulut. Oral health impac profile dikembangkan bertujuan untuk memberikan ukuran komprehensif tentang disfungsi, ketidak nyamanan dan kecacatan yang disebabkan oleh kondisi mulut. Pertanyaan untuk menilai kesehatan mulut pada penelitian ini diukur dengan skala likert yang terdiri dari 15 pertanyaan meliputi kesulitan dalam mengucapkan kata/kalimat (berbicara) karena permasalahan pada rongga mulut; tidak dapat mengecap rasa dengan baik; pernah merasakan sakit pada rongga mulut; merasa tidak nyaman saat mengunyah makanan; merasa tegang karena permasalahan pada rongga mulut; merasa tidak puas dengan makanan yang dikonsumsi; harus berhenti secara tiba-tiba saat sedang mengunyah makanan; mengalami kesulitan untuk merasa rileks/santai; merasa malu karena permasalahan pada rongga mulut; Apakah Anda pernah menjadi mudah tersinggung karena permasalahan mulut kering; merasa hidup kurang memuaskan; merasa susah untuk melakukan apapun; merasa kurang percaya diri karena mengalami permasalahan mulut kering saat kumpul bersama; pernah menggunakan obat untuk menghilangkan mulut kering; merasa kekeringan mulut yang di alami sekarang mengganggu aktivitas. 
Kuesioner ini menggunakan skala likert yaitu skor 0 untuk pilihan pernyataan tidak pernah (TP), skor 1 untuk pilihan pernyataan sangat jarang (SJ), skor 2 untuk pilihan pernyataan kadang-kadang (KK), skor 3 untuk pilihan pernyataan sering (S), dan 4 untuk pilihan pernyataan sangat sering (SS). Skor yang diperoleh kemudian dijumlahkan dan dibandingkan dengan skor maksimal sehingga didapat nilai kesehatan mulut responden yaitu untuk kesehatan mulut baik dengan skor (0-30) dan skor (31-60) untuk kesehatan mulut rendah. Pemberian permen karet xylitol diberikan kepada responden sebanyak 38 buah untuk dikunyah 15 menit setelah makan pagi pukul 08:00, makan siang pukul 13:00 dan makan malam pukul 19:00 selama 7 hari dengan waktu pengunyahan 5 menit.

\section{HASIL PENELITIAN}

\section{Analisis Univariat}

Tabel. 1

Karakteristik Pasien CKD dengan Xerostomia Berdasarakan Usia $(n=20)$

\begin{tabular}{llcc}
\hline Mean & SD & Min-Max & $95 \%$ CI \\
52,80 & 6,795 & $(36-63)$ & $49,62-55,98$
\end{tabular}

Berdasarkan tabel di atas diketahui rata-rata usia responden adalah 52 tahun dengan standar deviasi 6,795, usia terendah adalah 36 tahun dan usia tertinggi 63 tahun dan hasil estimasi interval dapat disimpulkan 95\% diyakini bahwa rata-rata usia responden adalah 49,62 sampai 55,98.

Tabel. 2

Karakteristik Pasien CKD dengan Xerostomia Berdasarakan Jenis Kelamin $(\mathrm{n}=20)$

\begin{tabular}{ccc}
\hline Jenis Kelamin & Frekuensi & Persentase \\
Laki-laki & 8 & $40 \%$ \\
Perempuan & 12 & $60 \%$ \\
Total & 20 & $100 \%$ \\
\hline
\end{tabular}

Berdasarkan tabel 2 di atas diketahui bahwa terdapat 20 orang responden, dimana jumlah responden perempuan lebih banyak jumlahnya dari pada responden laki-laki yaitu 12 orang $(60 \%)$ perempuan dan 8 orang $(40 \%)$ laki-laki.

Tabel. 3

Skor Kesehatan Mulut Sebelum dan Setelah Intervensi Pemberian Permen Karet Xylitol

\begin{tabular}{cccccc}
\hline $\begin{array}{c}\text { Kesehatan } \\
\text { Mulut }\end{array}$ & Mean & Median & SD & Min -Max & $95 \%$ CI \\
\hline Sebelum & 50,20 & 50,50 & 4,060 & $41-55$ & $48,30-52,10$ \\
\hline Setelah & 26,65 & 26,50 & 1,531 & $24-29$ & $25,93-27,37$
\end{tabular}


Hasil analisis data pada tabel 3 di atas didapatkan bahwa rata-rata skor kesehatan mulut responden sebelum intervensi pemberian permen karet xylitol adalah 50,20,sedangkan setelah intervensi meannya menurun menjadi 26,65. Rentang kepercayaan diyakini 95\% (CI 95\%) pada tabel diatas menunjukkan rata-rata skor kesehatan mulut responden sebelum intervensi pemberian permen karet xylitol berada pada rentang 48,30-52,10, sedangkan skor kesehatan mulut setelah intervensi berada pada rentang 25,93 - 27,37. Hasil analisis menunjukkan bahwa terjadi perbedaaan ratarata skor kesehatan antara sebelum dan setelah intervensi pemberian permen karet xylitol, yaitu terjadi penurunan skor yang menunjukkan bahwa kesehatan mulutnya dalam rentang kategori baik

\section{Analisis bivariat}

Tabel. 4

Analisis Rata-Rata Kesehatan Mulut Sebelum dan Setelah Intervensi Pemberian Permen Karet Xylitol

\begin{tabular}{lccccc}
\hline Variabel & Mean & SD & SE & P Value & \multicolumn{2}{c}{ N } \\
\hline Skor pre & 50,20 & 4,060 & 0,91 & 0,000 & 20 \\
Skor post & 26,65 & 1,531 & 0,34 & & \\
\hline
\end{tabular}

Berdasarkan hasil tabel 4 diatas menunjukkan rata-rata nilai kesehatan mulut sebelum dan setelah mengalami penurunan skor dari 50,20 menjadi 26,65 dengan hasil uji statistik didapatkan nilai $\mathrm{P}$ value adalah (0.000) sehingga nilai $\mathrm{P}$ value $>$ 0.05. Berarti ada perbedaan signifikan kesehatan mulut sebelum dan sesudah diberikan permen karet xylitol dengan keyakinan $95 \%$.

\section{PEMBAHASAN}

\section{Karakteristik Usia}

Hasil penelitian diketahui diketahui karakteristik usia responden sebagian besar kategori, usia 46-55 tahun (lansia awal) lebih banyak mengalami CKD dengan Xerostomia yang berjumlah 12 orang (60\%). Seiring dengan bertambahnya usia, organ tubuh mengalami penurunan fungsi atau bahkan kegagalan dalam menjalankan fungsinya.

Hal ini sejalan dengan teori yang menyatakan bahwa proses menua yang berlangsung setelah usia 30 tahun mengakibatkan perubahan anatomis, fisiologis dan biokimia. Perubahan dimulai dari tingkat sel, belanjut pada tingkat jaringan dan akhirnya pada tingkat organ yang dapat mempengaruhi fungsi homeostatis (Setiati, 2014).

Menurut Smeltzer, Bare \& Hinkle (2008) pada kasus penyakit ginjal kronis cenderung meningkat pada usia dewasa karena proses perjalanan penyakitnya yang bersifat kronis dan progresif. Semakin bertambahnya usia secara bersamaan fungsi renal dan traktus urinarius serta fungsi tubulus termasuk kemampuan reabsorbsi akan berkurang. Setelah usia 40 tahun laju filtrasi glomerulus akan mengalami penurunan secara progresif kurang dari 50\% dari normalnya hingga usia 70 tahun (Arfany, Armiyati \& Kusuma, 2014).

Pertambahan usia akan memengaruhi anatomi, fisiologi dan sitologi pada ginjal (Tjekyan, 2014; Prakash, 2009). Setelah usia 30 tahun, ginjal akan mengalami atrofi dan ketebalan kortek ginjal akan berkurang sekitar 20\% setiap dekade. Perubahan lain 
yang akan terjadi seiring dengan bertambahnya usia berupa penebalan membran basal glomerulus, ekspansi mesangium glomerular dan terjadinya deposit protein matriks ekstraselular sehingga menyebabkan glomerulosklerosis (Tjekyan, 2014; Hsieh, 2009).

Meningkatnya usia seseorang tentu saja akan memberikan dampak pada penurunan fungsi-fungsi tubuh sehingga semakin rentan terhadap penyakit. Usia juga berpengaruh pada prognosis suatu penyakit dan harapan hidup, usia responden penderita gagal ginjal kronik yang lebih dari 50 tahun tentunya lebih mudah untuk terjadi komplikasi dibandingkan dengan dengan penderita yang usianya dibawah 40 tahun (Putri, 2014; Bosniawan, 2018).

\section{Jenis Kelamin}

Hasil penelitian diketahui bahwa jumlah responden perempuan lebih banyak jumlahnya dari pada responden laki-laki yaitu 12 orang (60\%) perempuan dan 8 orang (40\%) laki-laki. Penelitian yang dilakukan oleh Arida, Azam \& Handayani (2017) menjelaskna bahwa secara statistik terdapat hubungan yang bermakna antara jenis kelamin dengan kejadian PGK pada pasien hipertensi. Tapi pasien yang lebih banyak mengalami PGK adalah laki-laki.

Secara klinik laki-laki mempunyai risiko mengalami penyakit ginjal kronik 2 kali lebih besar dari pada perempuan. Hal ini dimungkinkan karena perempuan lebih memperhatikan kesehatan dan menjaga pola hidup sehat dibandingkan laki-laki, sehingga laki-laki lebih mudah terkena penyakit ginjal kronik dibandingkan perempuan. Perempuan lebih patuh dibandingkan laki-laki dalam menggunakan obat karena perempuan lebih dapat menjaga diri mereka sendiri serta bisa mengatur tentang pemakaian obat (Pranandari, Supadmi, 2015).

\section{Pengaruh Pemberian Permen Karet Xylitol terhadap Kesehatan Mulut (Xerostomia) Pasien CKD}

Pengaruh permen karet xylitol sangat baik terhadap kesehatan mulut, beberapa negara telah merekomendasi kan penggunaan xylitol sebagai pengganti gula pada produk- produk makanan dan obat-obatan yang diproduksi, seperti permen karet, kembang gula, obat kumur, obat kunyah, dan pasta gigi.

Xylitol sejatinya adalah senyawa gula alkohol yang memiliki rumus kimia C5H12O5 dengan berat molekul sebesar 152,1. Xylitol memiliki rasa yang lebih manis dan lebih nikmat daripada gula lain, contohnya sorbitol. Kalori yang dikandung xylitol per gramnya $40 \%$ lebih rendah yaitu 2,4 kalori, dibandingkan dengan gula lain seperti sukrosa yang memiliki 4 kalori per gramnya. Dan apabila dilarutkan, panas pelarutan xylitol adalah negatif sepuluh kali lebih besar daripada sukrosa, sehingga xylitol akan menimbulkan sensasi dingin di dalam mulut.

Hasil penelitian ini sesuai dengan hasil penelitian yang dilakukan oleh Nimat (2016) tentang "analisa praktek klinik pada pasien Gagal Ginjal Kronik dengan intervensi inovasi mengunyah permen karet xylitol terhadap kerusakan membran mukosa oral akibat xerostomia" dengan hasil yaitu terdapat perbaikan mukosa oral yang menunjukkan mukosa lembab, pengurangan rasa haus. Sejalan dengan penelitian Prasetya (2018) tentang "permen karet xylitol xerostomia pada pasien penyakit ginjal kronis" menunjukkan hasil yaitu pengunyahan permen karet xylitol memiliki efek menurunkan keluhan xerostomia pada pasien penyakit ginjal kronis. 
Pasien dengan Xerostomia menurut teori self-care Orem dipandang sebagai individu yang memiliki kemampuan untuk merawat dirinya sendiri untuk memenuhi kebutuhan hidup, memelihara kesehatan dan mencapai kesejahteraan.

Pasien dengan Xerostomia dapat mencapai sejahtera/kesehatan yang optimal dengan mengetahui perawatan yang tepat sesuai dengan kondisi dirinya sendiri.

Peradangan pada rongga mulut dapat memicu respon sel dan kekebalan tubuh, yang akan ditransmisikan oleh aliran darah ke komponen lain dari sistem individu. Penyakit Parkinson berakibat pada rongga mulut, tidak hanya oleh disfungsi motorik, tetapi juga dengan pemberian obat-obatan yang dapat menyebabkan xerostomia. Mengenai gangguan ginjal, profesional gigi harus memberikan perhatian khusus terutama pada obat yang diresepkan untuk pasien, agar tidak meningkatkan risiko nefrotoksisitas. Terlepas dari fakta ini, studi ilmiah menunjukkan hubungan yang kuat antara gangguan metabolisme dan perkembangan penyakit mulut (Veiga, 2016).

\section{SIMPULAN}

Pemberian permen karet Xylitol berpengaruh terhadap kesehatan mulut (xerostomia) pasien CKD.

Berdasarkan hasil penelitian diketahui bahwa intervensi menggunakan permen karet xylitol dalam upaya untuk meningkatkan kesehatan mulut pada pasien yang menjalani Hemodialisa. Hal ini bisa dijadikan pertimbangan alternative pada saat melakukan intervensi keperawatan yang dapat dilakukan oleh perawat.

\section{SARAN}

Hasil penelitian ini diharapkan dapat digunakan sebagai evidance based practice dan menambah wawasan baru baik untuk pengajar maupun mahasiswa sehingga menjadi bahan pengembangan materi dan bisa diterapkan dalam aplikasi bagian dari intervensi mandiri keperawatan dan memasukkan dalam sub pokok bahasan Keperawatan Medikal Bedah khususnya materi intervensi pemberian permen karet xylitol dalam peningkatan kesehatan mulut (xerostomia) pada pasien CKD.

Penelitian ini diharapkan menjadi data dasar untuk penelitian berikutnya khususnya mengenai intervensi pada pasien CKD dan penelitian selanjutnya tidak hanya menggunakan metode kuantitatif tetapi juga kualitatif untuk mendapatkan informasi yang mendalam dengan mix methods. Selain itu diharapkan penelitian selanjutnya menggunakan sampel yang lebih besar dan menggunakan kelompok kontrol sebagai pembanding.

\section{DAFTAR PUSTAKA}

Agrianthy, Erlinda. (2014). Pengaruh Permen Karet Xylitol terhadap Plak Gigi: Fakultas Kedokteran Gigi. Universitas Sumatera Utara

Amelia. E. (2012). Hubungan Faktor Sosial Ekonomi \& Faktor yang Tidak Bisa Dimodifikasi Terhadap Diabtes Melitus Pada Lansia dan Prelansia di Kelurahan Depok Jaya, Depok, Jawa Barat Pada Tahun 2012. Skripsi. Depok: Universitas Indonesia

American Diabetes Association (ADA). (2018). American Diabetes Association Standards Of Medical Care In Diabetes-2018. https://diabetesed.net

American Diabetes Association. (2017). "Standards of Medical Care in Diabetes 2017”. Vol. 40. USA: ADA 
Arfany, N. W., Armiyati, Y., Kusuma, M. A. B. (2014). Efektifitas Mengunyah Permen Karet Rendah Gula dan Mengulum Es Batu terhadap Penurunan Rasa Haus pada Pasien Gagal Ginjal Kronis yang Menjalani Hemodialisis di RSUD Tugurejo Semarang. Jurnal Keperawatan dan Kebidanan (JIKK), 1-9

Arida, S. I., Azam, M., Handayani, O. W. K. (2017). Faktor yang Berhubungan dengan Kejadian Penyakit Ginjal Kronik pada Penderita Hipertensi di Indonesia. Jurnal MKMI, 13(4), 319-328

Bosniawan, A. M. A. (2018). Faktor-Faktor Determinan yang Berpengaruh pada Kualitas Hidup Penderita Gagal Ginjal Kronik di RSUD Sukoharjo. Naskah Publikasi. Universitas Muhammadiyah Surakarta

Dewi, P. F. (2008). Pengaruh Konsumsi Permen Karet yang Mengandung Xylitol Terhadap Pembentukan Plak Gigi. Skripsi. Fakultas Kedokteran Universitas Diponegoro, hal. 6

Hsieh, M. D. A. P. (2009). Abnormal Renal Function and Elecrolyte Disturbance in Older People. J Pharm Pract Res, 230-234

IDF. (2015). Atlas Diabetes Seventh. Vancouver, International Diabetes Federation. Website:http://www.diabetesatlas.org/

Kusuma. H \& Nurarif. A. H. (2012). Aplikasi Asuhan Keperawatan Berdasarkan NANDA (North American Nursing Diagnosis Association) NIC-NOC. Yogyakarta: Media Hardy

Marasabessy, F. A. (2013). Hubungan Volume dan pH Saliva pada Lansia. D, 55-60

Nimat, Y. (2016). Analisa Praktek Klinik Keperawatan pada Pasien Gagal Ginjal Kronik dengan Intervensi Inovasi Mengunyah Permen Karet Xylitol terhadap Perbaikan Membran Mukosa Oral akibat Xerostomia. STIK Muhammadiyah Samarinda

Prakash, S., Hare, A. M. (2009). Interaction of Aging and CKD. Senim Nephrol, 497503

Pranandari, R., Supadmi, W. (2015). Faktor Risiko Gagal Ginjal Kronik di Unit Hemodialisis RSUD Wates Kulon Progo. Majalah Farmaseutik, 11(2), 316-320

Prasetya, H. A., Istioningsih. (2018). Permen Karet Xylitol untuk Xerostomia pada Pasien Penyakit Ginjal Kronis. STIKK

Putri, R., Sembiring, L. P., \& Babasari, E. (2014). Gambaran Kualitas Hidup Pasien Gagal Ginjal Kronik yang Menjalani Terapi Contionuous Ambulatory Peritoneal Dialysis do RSUD 11 Arifin Achmad Provinsi Riau dengan Menggunakal Kuesioner KDQOL SF. Jurnal Online Mahasiswa (JOM) Bidang Kedokteran, $1(2)$

Rizky. (2013). Pengaruh Pemberian Permen Karet yang Mengandung Xylitol terhadap Penurunan Keluhan pada Lansia Penderita Xerostomia. Elsevier

Sari, N. N. G. (2011). Permen Karet Xylitol yang Dikunyah Selama 5 Menit Meningkatkan dan Mempertahankan pH Saliva Perokok Selama 3 Jam. Tesis. Universitas Udayana, hal. 53-54

Setiati, S., Sudoyo, A. W., Alwi, I., Simadibrata, M., Setiyohadi, B., Syam, F. A. (2014). Buku Ajar Ilmu Penyakit Dalam. Edisi 6. Jakarta: Interna, 2192-96

Smeltzer, S. C., Bare, B. G., Hinkle, J. L. (2008). Buku Ajar Keperawatan Medikal Bedah, Brunner \& Suddarth. Jakarta: EGC

Tjekyan, S. R. M. (2014). Prevalensi dan Faktor Risiko Penyakit Ginjal Kronik di RSUP Dr. Mohammad Hoesin Palembang Tahun 2012. (4), 275-282 
Veiga, N. (2016). The Influence of Chronic Disease in the Oral Health of the Elderly. Health Sciences Departemen Portuguesecatholic University

World Health Organization. (2016). Diabetes Fakta dan Angka. Diabetes di Dunia. Retrieved from https://www.google.com/url?sa=t\&rct=j\&q=\&esrc=s\&source=web\&cd=1\&cad=rj a\&uact=8\&ved=0ahUKEwi8gs2Cv4LZAhXMs48KHQCuA9oQFggwMAA\&url $=$ http $\% 3 \mathrm{~A} \% 2 \mathrm{~F} \% 2 \mathrm{Fwww}$.searo.who.int\%2Findonesia\%2Ftopics\%2F8-whd2016diabetes-facts-and-numbers-indonesian.pdf\&usg=AOvVaw0k4OGXSwGUF

Yuswir, A. R. R \& Rahayu, S. Y. (2014). Pengaruh Pemberian Permen Karet yang Mengandung Xylitol terhadap Curah dan $\mathrm{pH}$ Saliva pada Lansia Penderita Diabetes Mellitus Tipe 2. Jurnal Media Medika Muda 